\title{
Procedural and political aspects of forensic exhumation in Brazil
}

Marco Aurelio Guimarães Ribeirão Preto Medical School, University of São Paulo

mag@fmrp.usp.br

Raffaela Arrabaça Francisco Ribeirão Preto Medical School, University of São Paulo

raffaela.francisco@gmail.com

Martin Evison Faculty of Health and Life Sciences, Northumbria University

martin.evison@northumbria.ac.uk

Edna Sadayo Miazato Iwamura Department of Pathology,

Federal University of São Paulo

eiwamura@gmail.com

Carlos Eduardo Palhares Machado Ribeirão Preto Medical School, University of São Paulo; Brazilian Federal Police cadumachado@gmail.com

Ricardo Henrique Alves da Silva School of Dentristy of Ribeirão Preto, University of São Paulo

ricardohenrique@usp.br

Maria Eliana Castro Pinheiro Representatives of the Independent Group of Families of Political Dead and Disappeared from Brazilian Civil-Military Dictatorship mecp50@hotmail.com

Diva Santana Representatives of the Independent Group of Families of Political Dead and Disappeared from Brazilian Civil-Military Dictatorship santanadiva13@gmail.com

Julie Alvina Guss Patrício Representatives of the Independent Group of Families of Political Dead and Disappeared from Brazilian Civil-Military Dictatorship pagualju@yahoo.com.br 


\section{Abstract}

Exhumation may be defined as the legally sanctioned excavation and recovery of the remains of lawfully buried or - occasionally - cremated individuals, as distinct from forensic excavations of clandestinely buried remains conducted as part of a criminal investigation and from unlawful disinterment of human remains, commonly referred to as 'bodysnatching'. The aim of this article is to review the role of exhumation - so defined - in the activities of CEMEL, the Medico-Legal Centre of the Ribeirão Preto Medical School-University of São Paulo, in international, regional and local collaborations. Exhumations form part of routine forensic anthropology casework; scientific research in physical and forensic anthropology; and forensic casework conducted in collaboration with the Brazilian Federal Police; and are carried out as part of humanitarian investigations into deaths associated with the civil-military dictatorship of 1964 to 1985 . This article aims to offer a non-technical summary - with reference to international comparative information - of the role of exhumation in investigative and scientific work and to discuss developments in their historical and political context.

Key words: exhumation, forensic, anthropology, dictatorship, human rights, Brazil

\section{Introduction}

Exhumation may be defined as the legally sanctioned excavation and recovery of the remains of lawfully buried ${ }^{1}$ or - occasionally - cremated individuals, as distinct from forensic excavations of clandestinely buried remains conducted as part of a criminal investigation and from unlawful disinterment of human remains, commonly referred to as 'bodysnatching'.

Exhumations may be conducted for reasons as simple as relocation of the remains - in the case of urban redevelopment, for example - or for a variety of analytical purposes which universally arise from questions of doubt. Doubt may be related to the cause or manner of death, or to the identification of or confirmation of the identity of the deceased. In the UK, for example, the coroner may order an exhumation in relation to an inquest intended to answer the questions of who, where, when and how in relation to a death ${ }^{3}$ which may or may not be suspicious. An exhumation may, however, be ordered specifically for the purposes of criminal proceedings - including medical negligence - whether instituted or merely contemplated. ${ }^{4}$

Doubt also underlies exhumations for the purposes of scientific research, including the study of archaeological and taphonomic processes, anatomical and anthropological characteristics and genetic investigations. Exhumations may be undertaken in order to answer questions of archaeological, historical, cultural or political importance. Requests for legal authorisation may arise from the police, legal or judicial agencies, from relatives of the deceased and, occasionally, from researchers studying post-mortem processes and human remains. 
Exhumation is a highly socially sensitive, expensive and prolonged process. ${ }^{5}$ Reviewing the utility of exhumations undertaken in Cologne, Germany, Grellner and Glenewinkel ${ }^{6}$ note that exhumation is practised only when a certain need arises, and even then only if the questions in doubt might be resolved: an issue that may be dependent on the post-mortem interval. Breitmeier et al. examined exhumations in Hanover, Germany, and assert that 'an exhumation can answer a number of questions, although by consensus the success of an individual exhumation cannot be predicted'. The likelihood of success depends on the question to be answered and the extent of morphological changes and post-mortem decay. These processes remain important problems in forensic science, as these authors note: 'correlating the time in which a corpse has remained buried with particular physical findings on exhumation is not justified and would lead to a false sense of security regarding these findings, as no linear relationship exists between the time a corpse has remained buried and any degree of decay'. ${ }^{8}$ Nevertheless, in a review of 155 forensic exhumations in Münster, Germany, Karger et al. observed that a large majority of post-mortem examinations following exhumation were successful, the doubts that led to the exhumation being resolved completely in 65.8 per cent of cases and at least partially in most of the others. ${ }^{9}$ These findings reinforce the importance of exhumation as a forensic tool, taking into account its limitations without over-estimating its potential.

The frequency of exhumation is dependent on various factors such as jurisdiction - and related political or religious dimensions - and autopsy rate. It has been proposed that exhumation rates follow a principle of reciprocity, whereby low autopsy rates are associated with high exhumation rates and vice versa. ${ }^{10}$ In the UK, for example, where the use of post-mortem examinations in establishing the cause of death has been long accepted, only three or four coroner's exhumations are performed each year. ${ }^{11}$

Exhumations may involve the remains of only a single individual or of many - as in the case of a mass grave. In these cases, however, the original interment is frequently not lawful. The method of exhumation varies, depending on the problems in question and the expertise and experience of those responsible. ${ }^{12}$ With regard to mass graves, Skinner et al..$^{13}$ proposed international guidelines for forensic bioarchaeological monitoring of mass-grave exhumations directed towards the evaluation of quality. The analytical techniques employed in relation to an exhumation and post-mortem examination may involve forensic medicine and pathology, forensic odontology, forensic anthropology and archaeology, forensic chemistry and toxicology and forensic genetics. ${ }^{14}$

Applications of DNA technology ${ }^{15}$ in human identification and relationship analysis have grown rapidly since the pioneering work of Alec Jeffreys. ${ }^{16}$ Examples include US military personnel missing from the Vietnam War, subsequently identified by mitochondrial DNA (mtDNA) analysis; ${ }^{17}$ authentication of the remains of Czarina Alexandra and Tsar Nicolas II - killed in 1918 - by comparison of the mtDNA sequences obtained with those of maternal relatives, living and deceased; ${ }^{18}$ and identification of individuals killed during the Argentine military dictatorship of 1976 to 1983 , also identified by mtDNA analysis. ${ }^{19}$ 
The aim of this article is to offer a non-technical summary of the work of the Medico Legal Centre (CEMEL) of Ribeirão Preto Medical School-University of São Paulo (FMRP-USP), an academic centre for forensic medicine. The Centre performs exhumations for a range of purposes including in routine forensic anthropology casework, scientific research in physical and forensic anthropology and forensic casework conducted in collaboration with the Brazilian Federal Police. CEMEL has also undertaken exhumations as part of humanitarian investigations into deaths associated with the civil-military dictatorship of 1964 to 1985 . The use and role of exhumations are discussed within their historical and political context.

\section{The Medico Legal Centre of Ribeirão Preto Medical School- University of São Paulo}

Inaugurated in 1999, CEMEL is part of the Department of Pathology and Legal Medicine of FMRP-USP, located in the city of Ribeirão Preto. This Centre was the first in Brazil to have resulted from a formal agreement between a university and the Secretary of State for Public Security, established with the aim of developing forensic medicine in practice, research and education. ${ }^{20}$ The Centre has been recognised internationally as an example of a new model for forensic medicine in Brazil. ${ }^{21}$ Collaboration with the Sheffield Medico-Legal Centre, supported by the United Kingdom Foreign and Commonwealth Office Global Opportunities Fund in 2003, ${ }^{22}$ led to the establishment of the Laboratory of Forensic Anthropology (LAF-CEMEL), supported by training in forensic anthropology and pathology and the development of a forensic anthropology protocol - the LAF-CEMEL protocol - tailored to the characteristics and necessities of the Brazilian environment ${ }^{23}$ and supported by an online system. ${ }^{24}$ The LAF-CEMEL protocol is a standardised protocol for analysis, recording and reporting of forensic anthropology cases, incorporating osteological data, pathology, trauma, possessions etc.

With capacity for forensic anthropological analysis of human remains established, CEMEL responded to demand in four main areas: (i) forensic anthropological analysis and sample collection for DNA analysis in collaboration with the regional Death Verification Service (Serviço de Verificação de Óbitos do Interior, SVOI) and police forensic investigators (Polícia Técnico-Científica); (ii) scientific research in physical and forensic anthropology aimed at the development of forensic anthropology procedures and reference standards; (iii) forensic homicide investigation undertaken in collaboration with the Brazilian Federal Police and (iv) via a contribution to the search for the political disappeared from the time of the civil-military government of Brazil of 1964 to 1985.

\section{Routine forensic anthropology casework}

The agreement between the University of São Paulo and the Secretary of State for Public Security (NPML-RPO) resulted in a protocol for human identification in routine cases involving partially or fully skeletonised human remains. Francisco et al. ${ }^{25}$ reported that from 1999 to 2006 the average number of bones for each 
body or skeleton forwarded to CEMEL was 79.57. After the establishment of LAF-CEMEL in 2005 and the implementation of the NPML-RPO agreement, the average number of bones forwarded increased to 112.83 per skeleton, attributed to improved capacity and performance and an increased expectancy that remains would be identified. On average, 30 to 35 per cent of cases forwarded for analysis annually are identified, frequently as a consequence of collaborative work with the forensic odontology team of the School of Dentistry of Ribeirão Preto-University of São Paulo. ${ }^{26}$ Multidisciplinary collaborative contributions from forensic archaeology, anthropology, odontology, pathology and genetics underpin a team-based approach to investigation and identification. Burial locations are typically those encountered in the tropical soils of the Ribeirão Preto region. ${ }^{27}$

Prior to implementation of the protocol the rate of identification was negligible, with identifications occurring only rarely, and then fortuitously. Thus, implementation the NPML-RPO agreement and the LAF-CEMEL protocol led to a substantial increase in applications for $^{28}$ and success in identifications. The CEMEL case demography is described by international comparison by Evison et al. ${ }^{29}$ which also addresses questions of the utility and efficacy of forensic anthropology casework.

Sample collection for DNA analysis ${ }^{30}$ has become an important component of routine forensic anthropology casework at CEMEL, conducted in collaboration with the SVOI and police forensic investigators. Human identification by DNA analysis in forensic anthropology cases usually involves comparison of a 'questioned' sample from the unidentified individual - usually derived from the bones, teeth or soft tissues - with a reference sample collected from intimate items from the person in question or from family members. Analysis of mtDNA is commonly undertaken, as this can be accomplished more readily from highly degraded or fragmented DNA samples. This analysis is restricted to comparison with reference samples from maternal relatives of the person in question, however, and may be insufficient for individual identification. In contrast, analysis of short tandem repeat (STR) markers found in the cell nucleus, including those of the X and Y chromosomes, may be used very informatively - individually or in combination - but these are less readily recovered from highly decomposed samples. The latter issue is of critical importance in the context of Brazil, where strategies for DNA analysis of highly decomposed remains recovered from burials in tropical soils are a priority (see below). DNA profiling is not always successful or even possible - for example, in the absence of a candidate identity or reference sample - and forensic anthropological and other findings maybe adequate for identification to be confirmed by other means or to facilitate or substantiate identifications subsequently clarified by genetic analysis.

\section{Scientific research in physical and forensic anthropology}

Following its establishment in 2005, LAF-CEMEL relied on standards in identification from bone derived from non-Brazilian populations ${ }^{31}$ based on the assessment of sex, ancestry, age, stature, handedness, dental characteristics, pathological findings and the presence of clothes and other belongings. ${ }^{32}$ 
Application of the LAF-CEMEL protocol led to recognition that the application of non-Brazilian standards in forensic anthropology may not be appropriate to the Brazilian population - noted for its extensive admixture.

In order to assess the efficacy of the protocol a blind study was undertaken on 120 skeletons, 90 of which were exhumed from the Bom Pastor Cemetery in Ribeirão Preto prior to their relocation in a general ossuary. Thirty of the remains were of indigent people who had died from natural causes and had been autopsied at CEMEL by the SVOI. Not having been claimed by relatives, these remains had been buried in the cemetery with data relating to their identification retained in case of a subsequent search. After five years of burial, legal authorisation was obtained for the remains to be exhumed for scientific research. These exhumations were undertaken with the cooperation of the civic development agency CODERP (Companhia de Desenvolvimento Econômico de Ribeirão Preto) following review by the ethical committee of the University of São Paulo. The results of the anthropological analysis were compared with the ante-mortem profiles recorded by the administration of the Bom Pastor Cemetery at the time of interment in order to measure compatibility between ante-mortem and post-mortem assignments. Improved performance was associated with a better state of bone preservation, in results comparable with general estimates of the reliability of forensic osteological assessments. ${ }^{33}$ The study also highlighted the value, in the case of unidentified bodies, of recording stature and handedness prior to burial. Although based on parameters derived from populations external to Brazil, the LAF-CEMEL protocol was shown to be generally suitable for skeletal analysis, including in cases of mixed ancestry. Nevertheless, the protocol is based in decision tables incorporating multiple morphological features rather than - with the exception for stature estimation - anthropometric methods. Difficulties arising from the application of reference standards from non-representative samples ${ }^{34}$ indicate a demand for the development of standards more appropriate to the Brazilian population.

Finally, the pattern of casework encountered by LAF-CEMEL was analysed by comparison with other similar and larger centres in Latin America, the US and the UK and was shown to reflect a trend that appears applicable to most jurisdictions - only varying substantially according to such factors as homicide rate and climatically associated rate of skeletonisation. ${ }^{35}$ This comparison also identified a series of factors contributing to investigative case progression in forensic anthropology - including the key significance of identification of the victim to the detection and prosecution of the crime, and the need for advancement of education and research.

In Brazil, considerable research effort has been directed towards improved genetic identification from complex samples such as exhumed bones and other challenging biological material, ${ }^{36}$ as well as to frequency studies of DNA markers in the Brazilian population that can be used in calculations of probability. ${ }^{37} \mathrm{Hard}-$ tissue specimens recovered from the thirty skeletons of indigent people described above were investigated in a combined histological and DNA analysis conducted in collaboration with the Laboratory of Molecular Pathology in the Department of Pathology-Escola Paulista de Medicina/Federal University of São Paulo. This was 
intended to improve understanding of post-mortem diagenesis and to develop applications for DNA analysis of skeletal specimens from tropical soils, in order to optimise genetic and anthropological protocols ${ }^{38}$ - as well as those involving other physico-chemical approaches. Melki et al., ${ }^{39}$ for example, described procedures for the genetic investigation of bones from individual exhumations. These procedures were also shown to be useful for individual exhumations in which the objective was the investigation of vital reactions related to the cause of death using scanning electron microscopy. ${ }^{40}$

\section{Forensic casework conducted in collaboration with the Brazilian Federal Police}

Expertise in forensic odontology and pathology was acquired by the Brazilian Federal Police in 2006 and 2007, respectively. In 2010, CEMEL established a partnership with the Federal Police and began training its forensic experts in LAFCEMEL procedures. The partnership has so far led to the collaborative investigation of four highly complex cases involving exhumations in which discretion was essential, due to their high media profile. Use of LAF-CEMEL staff and facilities CEMEL is located at a considerable distance from the original places of occurrence of the cases - assisted in securing confidentiality.

Imaging examinations using computed tomography were undertaken at FMRPUSP and recovery and preservation of tattooed skin, histological examinations and removal of soft tissue in preparation for forensic anthropological examination were undertaken at CEMEL. Final analysis and reports on findings - which presently remain sub judice - were undertaken in collaboration with the Federal Police.

This partnership now extends to research in the photoanthropometry of facial development, with the aim establishing reliable parameters for age estimation in images of child pornography and in cases of disappeared young people.

A particularly noteworthy case in which CEMEL performed exhumation and analysis in collaboration with the Brazilian Federal Police was that of Arnaldo Cardoso Rocha. Rocha was a political activist killed during the dictatorship era, allegedly following a confrontation with the police. Exhumation followed by a comprehensive post-mortem analysis revealed evidence of torture and execution, contradicting the contemporary account.

\section{Humanitarian investigation}

Collaborative work with the Brazilian Federal Police led to an invitation to participate in the search for the political disappeared from the civil-military government of 1964 to 1985 . CEMEL has contributed to the investigations of the Araguaia Working Group (GTA). The GTA was established in 2011 with the aim of sustaining the work of a pre-existing group attempting to locate and identify the remains of the dead of the Araguaia Guerrilla War of 1966 to $1974 .{ }^{41}$ Working with forensic anthropologists, archaeologists, odontologists and pathologists from the medico-legal institutes of Brasília, Goiannia, the Ministry of Defence and the 
Ministry of Justice, and the Brazilian Federal Police, CEMEL participated in the GTA's investigations from 2012 to 2014, including in numerous searches for, and excavations and exhumations of, human remains anticipated to be those of guerrillas killed during the dictatorship era. These investigations were undertaken in the Amazonia region, in locations at the margin of settlement, where exhumations have taken place in the forests, on farm land established only in recent decades and in municipal cemeteries in remote towns.

After two years of collaboration in the GTA investigations CEMEL withdrew from its activities, as well as from related investigations in São Paulo, ${ }^{42}$ citing disagreements related to the investigative methods proposed. In the opinion of the CEMEL team, analysis of trauma was being neglected and certain procedures (such as washing of bones) were thought to impede subsequent histological and physicochemical analysis - for the purposes of detection of gunshot residue, for example. CEMEL contended that the GTA was too reluctant to accept other scientific and international contributions, especially with regard to planning.

\section{Discussion}

Forensic medicine in Brazil is only gradually recovering from the consequences of two decades of dictatorship. The infrastructure outside urban centres was - and frequently still is - poor. Autopsies are often done in small rooms in cemeteries with limited laboratory support, using outdated technology and where it may be difficult to protect the chain of custody. In these circumstances, conditions can lead to a disincentive to conduct thorough casework.

The establishment of CEMEL as a centre for best practice is a development of national and international significance, notably underpinned by UK Foreign and Commonwealth Office support for capacity-building partnerships with the Sheffield Medico-Legal Centre and by collaborations with the School of Dentistry of USP, the regional Death Verification Service (Serviço de Verificação de Óbitos do Interior) and police forensic investigators (Polícia Técnico-Científica) particularly in relation to sample collection for DNA analysis from skeletonised and partially skeletonised human remains. The CEMEL team constitutes forensic anthropologists, pathologists and technicians, further supported by contributions from specialist forensic odontologists from the FMRP-USP. CEMEL's research currently sustains national and international scientific collaborations addressing a range of problems in forensic science and medicine.

These developments must be seen in contrast to the prevailing practice preceding Brazil's transition to democracy, prior to which the criminal law relied on statutes implemented during the dictatorship of Getúlio Vargas (1937-45), which gave control of forensic investigations to the police (Polícia Civil). This left investigations vulnerable to political manipulation and prevented independent verification and academic scrutiny and the development of education and research in forensic science and medicine. Poor standards contributed to poor outcomes in investigations, frequently serving a dictatorial government. ${ }^{43}$ In the opinion of Guimarães et al., ${ }^{44}$ 'Keeping victims unidentified meant that government institutions could avoid 
being the target of criticism or investigation. Political crimes could be hidden and members of the political opposition - mainly from left-wing political parties - could be "disappeared". 'Empirical studies of the number of 'disappeared' are limited and the officially accepted figure of 437 to 475 may be an under-estimate, as it does not include deaths not associated with political parties and unreported deaths. ${ }^{45}$

The GTA was mandated as the consequence of an agreement between the First Federal Court of Brasília and the Inter-American Court of Human Rights of the Organisation of American States and was established following the enactment of Inter-Ministry Ordinance no. $1,{ }^{46}$ authorised by signatories from the Ministry of Justice, Ministry of Defence and the National Secretary for Human Rights. The GTA is probably the most substantial public initiative in Brazil with the main objective of the location of burials in official or clandestine cemeteries or in open areas, including fields and forests - Araguaia is located in the Amazon region. Relatives of the disappeared are represented by the Independent Group of Families of the Political Dead and Disappeared from the Brazilian Civil-Military Dictatorship. Initially, families organised expeditions at their own expense, the first one being in 1980. Since then, the remains of nine individuals have been exhumed based on their initiatives. Two have subsequently been identified by DNA analysis. Since 2009, exhumations - to which CEMEL has contributed - have been undertaken by the GTA and its precursor organisation. Families' representatives report that the remains of another twenty individuals, suspected to be those of the Araguaia guerrilla group, have been exhumed, but no further identifications have been obtained.

There is a common perception among representatives of families that these investigations are disorganised and are lacking not only resources but also in commitment from the Brazilian government. There is a further perception that the exhumations are no more than a political response to the judicial condemnation that the Brazilian State has received at national and international levels, rather than any real humanitarian interest in identification of remains and informing relatives of the victim's fate.

CEMEL's decision to leave GTA and the reasons for the decision were announced openly to representatives of the Independent Group of Families of Political Dead and Disappeared from the Brazilian Civil-Military Dictatorship.

Other social and scientific aspects of this work are discussed in detail in Guimarães et al., ${ }^{47}$ with critical reference to the role of forensic investigations in transitional justice. Further investigations and exhumations in relation to the civil-military dictatorship require a fundamental commitment to, and plan for, concerted action and the establishment of an independent body that can monitor and ensure progress and respond to the demands of victims' families.

\section{Conclusions}

Legal exhumations undertaken by CEMEL underpin routine casework, scientific research, casework conducted in collaboration with the Brazilian Federal Police and humanitarian investigations of alleged homicides committed during the military government of 1964 to 1985 . 


\section{Marco Aurelio Guimarães et al.}

Routine casework is enabled via an agreement between the USP and the São Paulo Secretary of State for Public Security and involves collaboration with the regional Death Verification Service and police forensic investigators. Subsequent forensic analysis involves multidisciplinary collaborations between forensic anthropologists, odontologists and pathologists, and police forensic experts in DNA profiling. Implementation of the partnership agreement and capacity building supported by the UK Foreign and Commonwealth Office has led to a measurable improvement in the quality of forensic anthropology casework and frequency of identifications.

CEMEL has developed scientific research based on reference material recovered from legal exhumations obtained in partnership with the local civic development agency. This research is aimed at developing forensic osteology standards more applicable to the Brazilian population and also underpins studies examining hard tissue and DNA diagenesis in skeletal material recovered from soils in challenging Brazilian tropical climates, and which are aimed at improving forensic DNA profiling from these substrates.

CEMEL collaborates with the Brazilian Federal Police in exhumations undertaken in investigations that may be politically sensitive, including some relating to alleged human rights abuses by the military government. CEMEL has contributed to wider humanitarian work as part of the GTA. Humanitarian work is particularly susceptible to political agendas that may compromise academic independence.

\section{Notes}

1 P. J. Saukko and B. Knight, Knight's Forensic Pathology (Boca Raton, CRC Press, 2004), 36-7.

2 J. Hunter and M. Cox, Forensic Archaeology: Advances in Theory and Practice (London, Routledge, 2005).

3 C. P. Dorries, Coroners' Courts: A Guide to Law and Practice (London, Wiley, 1999).

4 Ibid., 317.

5 F. H. Mirza, S. E. Adil, A. A. Memon and H. Ali Paryar, 'Exhumation - Nuisance to the Dead, Justified?', Journal of Forensic and Legal Medicine, 19:6 (2012), 337-40, doi: 10.1016/j.jflm.2012.02.018.

6 W. Grellner and F. Glenewinkel, 'Exhumations: Synopsis of Morphological and Toxicological Findings in Relation to the Postmortem Interval. Survey on a 20-Year Period and Review of the Literature', Forensic Science International, 90 (1997), 139-59.

7 D. Breitmeier, U. Graefe-Kirci, K. Albrecht, M. Weber, H. D. Tröger and W. J. Kleemann, 'Evaluation of the Correlation Between Time Corpses Spent in In-Ground Graves and Findings at Exhumation', Forensic Science International, 154:2-3 (2005), 218-23, 218.

8 Ibid., 222.

9 B. Karger, G. Lorin de la Grandmaison, T. Bajanowski and B. Brinkmann, 'Analysis of 155 Consecutive Forensic Exhumations with Emphasis on Undetected Homicides', International Journal of Legal Medicine, 118:2 (2004), 90-4. 
10 Ibid.; Grellner and Glenewinkel, 'Exhumations: Synopsis of Morphological and Toxicological Findings',; F. Dedouit, M. D. Piercecchi-Marti, G. Leonetti, D. Rougé and N. Telmon, 'Cause of Internal Hemorrhage Determined after Exhumation: Report of One Case’, Forensic Science International, 204:1-3 (2011), e20-3, doi: 10.1016/j.forsciint.2010.05.028.

11 Dorries, Coroners' Courts, p. 84.

12 W. M. Krogman and M. Y. Işcan, The Human Skeleton in Forensic Medicine (Springfield, IL, Charles C. Thomas, 1986); D. H. Spennemann and B. Franke, 'Archaeological Techniques for Exhumations: A Unique Data Source for Crime Scene Investigations', Forensic Science International, 74:1-2 (1995), 5-15.

13 M. Skinner, D. Alempijevic and M. Djuric-Srejic, 'Guidelines for International Forensic Bio-Archaeology Monitors of Mass Grave Exhumations', Forensic Science International, 134:2-3 (2003), 81-92.

14 J. M. Butler, Forensic DNA Typing (New York, Academic Press, 2005); S. N. Byers, Introduction to Forensic Anthropology (Boston, Pearson Education, 2008); Saukko and Knight, Knight's Forensic Pathology.

15 Butler, Forensic DNA Typing.

16 A. J. Jeffreys, J. F. Y. Brookfield and R. Semeonoff, 'Positive Identification of an Immigration Test-Case Using Human DNA-Fingerprints', Nature, 317:6040 (1985), 818-19.

17 M. M. Holland, D. L. Fisher, L. G. Mitchell, W. C. Rodriquez, J. J. Canik, C. R. Merril and V. W. Weedn, 'Mitochondrial DNA Sequence Analysis of Human Skeletal Remains: Identification of Remains from the Vietnam War', Journal of Forensic Sciences, 38 (1993), 542-53.

18 P. Gill, P. L. Ivanov, C. Kimpton, R. Piercy, N. Benson, G. Tully, I. Evett, E. Hagelberg and K. Sullivan, 'Identification of the Remains of the Romanov family by DNA Analysis', Nature Genetics, 6 (1994), 130-5.

19 D. Corach, A. Sala, G. Penacino, N. Iannucci, P. Bernardi, M. Doretti, L. Fondebrider, A. Ginarte, A. Inchaurregui, C. Somigliana, S. Turner and E. Hagelberg, 'Additional Approaches to DNA Typing of Skeletal Remains: The Search for "Missing" Persons Killed during the Last Dictatorship in Argentina', Electrophoresis, 18:9 (1997), 1608-12.

20 M. A. Guimarães, 'The Challenge of Identifying Deceased Individuals in Brazil: From Dictatorship to DNA Analysis', Science and Justice 43:4 (2003), 215-17.

21 D. Adam, 'Brazilian Forensic Medicine: Back from the Dead', Nature, 423:6935 (2003), 13-14.

22 FCO, Science and Innovation Annual Report 2004-2005 (London, Foreign and Commonwealth Office, 2005), 74.

23 A. T. C. Soares and M. A. Guimarães, 'Two Years of Forensic Anthropology at the Medico Legal Centre (CEMEL) of the Faculty of Medicine of Ribeirão Preto-USP', Medicina (Ribeirao Preto), 41:1 (2008), 7-11; R. A Francisco, A. P. S Velloso, T. C. P. Silveira, J. M. Secchieri and M. A. Guimarães, 'Forensic Anthropology at Medico Legal Centre of the Faculty of Medicine of Ribeirão Preto/USP - Comparative Study of Cases from 1999-2009', Medicina (Ribeirão Preto), 44:3 (2011), 241-8; R. A. Francisco, R. H. A. Silva, J. M. Pereira, E. G. Soares, E. Matheucci Júnior, E. S. M. 
Iwamura and M. A. Guimarães, 'Forensic Anthropology Screening for Analyses of Forensic Genetics', Saúde, Ética \& Justiça, 18:1 (2013), 128-33.

24 L. G. Crocco, G. O. Brondi, A. T. C. Soares, J. C. Felipe, M. P. Evison and M. A. Guimarães, 'LAF 1.0: Establishment of a Computerized System for Laboratories of Forensic Anthropology', Medicina (Ribeirão Preto), 41 (2008), 12-6, doi: 10.11606.

25 Francisco et al., 'Forensic Anthropology at Medico Legal Centre of the Faculty of Medicine of Ribeirão Preto/USP'.

26 M. Palinkas, M. Semprini, R. A. Francisco, C. B. Simões, M. A. Guimarães and R. H. A. Silva, 'Morphological Analysis of Dental Remains of a Human Skeleton Found in a Mountain-Shell (Sambaqui) in Ilha Bela Archipelago on the Northern Coast of São Paulo, State, Brazil, Saúde, Ética \& Justiça, 15:2 (2010), 75-9; A. S.

S. D. Terada, N. L. P. Leite, T. C. P. Silveira, J. M. Secchieri, M. A. Guimarães and R. H. A. Silva, 'Human Identification in Forensic Dentistry from a Photographic Record of Smile: A Case Report', Revista Odontologica UNESP, 40:4 (2011), 199-202; I. G. C. Caputo, J. N. Reis, T. C. P. Silveira, M. A. Guimarães and R. H. A Silva, 'Identification of a Charred Corpse Through Dental Records', Revista RSBO 8:3 (2011), 345-51; A. S. S. D. Terada, L. G. Araujo, L. R. Paranhos, T. C. P. Silveira, M. A. Guimarães and R. H. A. Silva, 'Orthodontic Use of Documentation in Identification of a Skeletonized Body in Legal Dental Practice', International Journal of Odontostomatology, 8:1 (2014), 41-6.

27 M. P. Evison, R. A. Francisco and M. A. Guimarães, 'Approaching Utility in Forensic Anthropology', Forensic Science Policy and Management: An International Journal, 3:2 (2012), 85-104; M. P. Evison, R. A. Francisco and M. A. Guimarães, 'Utility in Forensic Anthropology: Findings Contributing to Case Conversion', Forensic Science Policy and Management: An International Journal, 3:2 (2012), 113-25.

28 Soares and Guimarães, 'Two Years of Forensic Anthropology at the Medico Legal Centre (CEMEL) of the Faculty of Medicine of Ribeirão Preto-USP'; Francisco et al., 'Forensic Anthropology at Medico Legal Centre of the Faculty of Medicine of Ribeirão Preto/USP'; Francisco et al., 'Forensic Anthropology Screening for Analyses of Forensic Genetics'.

29 Evison et al., 'Approaching Utility in Forensic Anthropology'; Evison et al., 'Utility in Forensic Anthropology: Findings Contributing to Case Conversion'.

30 Butler, Forensic DNA Typing.

31 Soares and Guimarães, 'Two Years of Forensic Anthropology at the Medico Legal Centre (CEMEL) of the Faculty of Medicine of Ribeirão Preto-USP'; Francisco et al., 'Forensic Anthropology at Medico Legal Centre of the Faculty of Medicine of Ribeirão Preto/USP'; Francisco et al., 'Forensic Anthropology Screening for Analyses of Forensic Genetics'.

32 A. M. Albert and W. R. Maples, 'Stages of Epiphyseal Union for Thoracic and Lumbar Vertebral Central as a Method of Age Determination for Teenage and Young Adult Skeletons', Journal of Forensic Sciences, 40 (1995), 622-33; W. M. Bass, Human Osteology: A Laboratory and Field Manual (Columbia, Missouri Archaeological Society, 1995); S. Brooks and J. Suchey, 'Skeletal Age Determination base on the Os Pubis: A Comparison of the Acsádi-Nemeskéri and 
Suchey-Brooks Methods', Human Evolution, 5 (1990), 227-38; J. E. Buikstra and D. H. Ubelaker, 'Standards for Data Collection from Human Skeletal Remains', Arkansas Archaeological Survey Research Series, 44 (1994); K. R. Burns, Forensic Anthropology Training Manual (Upper Saddle River, NJ, Prentice Hall, 1999); Byers, Introduction to Forensic Anthropology; S. I. Fairgrieve and T. S. Oost, Human Skeletal Anatomy: Laboratory Manual and Workbook (Springfield, IL, Charles C. Thomas, 2001); S. C. Genovés, 'Proportionality of Long Bones and Their Relation to Stature among Mesoamericans', American Journal of Physical Anthropology, 26 (1967), 67-78; G. W. Gill and S. Rhine, 'Skeletal Attribution of Race', 2nd printing, Maxwell Museum of Anthropology Anthropological Papers (New Mexico, University of Albuquerque, 1990); M. Y. Isçan, S. R. Loth and R. K. Wright, 'Age Estimation from the Ribs by Phase Analysis: White Males', Journal of Forensic Sciences, 29 (1984), 1094-104; M. Y. Isçan, S. R. Loth and R. K. Wright, 'Metamorphosis at the Sternal Rib End: A New Method to Estimate Age at Death in White Males', American Journal of Physical Anthropology, 65 (1984), 147-56; C. O. Lovejoy, R. S. Meindl, R. P. Mensforth and T. J. Barton, 'Multifactorial Determination of Skeletal Age at Death: A Method and Blind Tests of Its Accuracy', American Journal of Physical Anthropology, 68 (1985), 1-14; M. Trotter and G. C. Gleser, 'Estimation of Stature from Long Limb Bones of American Whites and Negroes', American Journal of Physical Anthropology, 10:4 (1952), 463-514; M. Trotter and G. C. Gleser, 'Corrigenda to Estimation of Stature from Long Limb Bones of American Whites and Negroes', American Journal of Physical Anthropology, 47 (1977), 355-6; A. P. S. Veloso, R. A. Francisco and M. A. Guimarães, 'Antropologia Forense', in J. A. Velho, G. C. Geiser and A. Espindula (eds), Ciências Forenses - Uma introdução às principais áreas da Criminalística Moderna (São Paulo, Editora Millenium, 2013); T. D. White, M. T. Black and P. A. Folkens, Human Osteology (London, Academic Press, 2012); T. D. White and P. A. Folkens, The Human Bone Manual (San Diego, Elsevier Academic Press, 2005).

33 M. P. Evison, 'Forensic Anthropology and Human Identification from the Skeleton', in J. Fraser and R. Williams (eds), Handbook of Forensic Sciences (London, Willan, 2009), pp. 84-112.

34 Ibid.

35 Evison et al., 'Approaching Utility in Forensic Anthropology'; Evison et al., 'Utility in Forensic Anthropology: Findings Contributing to Case Conversion'.

36 E. S. M. Iwamura, J. A. Soares-Vieira and D. R. Muñoz, 'Human Identification and Analysis of DNA in Bones', Revista do Hospital das Clínicas, 59:6 (2004), 383-8; E. S. M. Iwamura, C. R. G. C. M. Oliveira, J. A. Soares-Vieira, S. A. B. Nascimento and D. R. Muñoz, 'A Qualitative Study of Compact Bone Microstructure and Nuclear Short Tandem Repeat Obtained from Femur of Human Remains Found on the Ground and Exhumed Three Years after Death', American Journal of Forensic Medicine and Pathology, 26:1 (2005), 33-44, doi: 10.1097/01.paf.0000154116.30837.d5; E. S. M. Iwamura, J. A. Soares-Vieira, M. S. Silva, K. S. Funabashi, C. D. Godoy and D. R. Muñoz, 'Analysis of DNA Profiles Extracted from Degraded Samples from Archival of Formalin Fixed Tissue Included in Paraffin (FFTIP) and Hairs', Forensic Science International: 
Genetics Supplement Series, 2:1 (2009), 167-8, doi: 10.1016/j.fsigss.2009.08.096; M. P. Soler, M. T. S. Alves, M. S. Silva, M. A. Guimarães, M. L. A. P. O. Sousa, J. S. Almeida and E. S. M. Iwamura, 'Morphological and DNA Analysis in Human Skeletal Remains Exposed to Environmental Conditions in Brazil', Forensic Science International: Genetics Supplement Series, 3:1 (2011), e339-e40, doi: 10.1016/j. fsigss.2011.09.032; M. P. Soler, M. S. Silva, M. A. Guimarães, M. L. A. P. O. Sousa, R. S. Stilhano, S. W. Han and E. S. M. Iwamura, 'STR Analysis in Bones Exposed to Brazilian Tropical Climate', Forensic Science International: Genetics Supplement Series, 3:1 (2011), e550-1, doi: 10.1016/j.fsigss.2011.10.017; K. S. Funabashi, D. Barcelos, I. Visoná, M. S. Silva, M. L. A. P. O. Sousa, M. F. de Franco and E. S. M. Iwamura, 'DNA Extraction and Molecular Analysis of Non-Tumoral Liver, Spleen, and Brain from Autopsy Samples: The Effect of Formalin Fixation and Paraffin Embedding', Pathology Research and Practice, 208:10 (2012), 584-91, doi: 10.1016/j.prp.2012.07.001.

37 J. A. Soares-Vieira, A. E. C. Billerbeck, E. S. M. Iwamura, B. B. Mendonca, L. Gusmão and P. A. Otto, 'Population and Mutation Analysis of Y-STR Loci in a Sample from the City of São Paulo (Brazil)', Genetics and Molecular Biology, 31:3 (2008), 651-6; E. S. M. Iwamura, J. A. Soares-Vieira, J. C. Ponce, D. F. Zamarrenho, A. C. Cruvinel, M. G. Pradal and D. R. Muñoz, 'Paternity Investigation Analysis in Artificial Mother-Deficient Cases Using STR Loci in the Brazilian Population', Forensic Science International: Genetics Supplement Series, 1:1 (2008), 516-17, doi: 10.1016/j.fsigss.2007.10.219; C. D. Godoy, I. S. Kunii, K. S. Funabashi, J. M. Cerutti, M. L. A. P. O. Sousa, D. M. Sinagawa, J. A. Soares-Vieira, D. R. Muñoz and E. S. M. Iwamura, 'Mitochondrial DNA in a Population of Individuals from the City of São Paulo. DNA Extraction from Head and Pubic Hair and Blood', Forensic Science International: Genetics Supplement Series, 3:1 (2011), e149-50, doi: 10.1016/j. fsigss.2011.08.075; M. L. A. P. O. Sousa, M. A. T. De Oliveira, E. A. Auler-Bittencout, J. A. Soares-Vieira, D. R. Munoz and E. S. M. Iwamura, 'Population Data of 16 Autosomal STR Loci of the Powerplex ESX 17 System in a Brazilian Population from the State of São Paulo', Forensic Science International: Genetics, 11:1 (2014), e15-17, doi: 10.1016/j.fsigen.2014.03.018; E. Auler-Bittencourt, E. S. M., Iwamura, M. J. M., Lima, I. D. C. G., da Silva and S. E. B. dos Santos, 'Exploring the Applicability of Analysing X Chromosome STRs in Brazilian Admixed Population', Science and Justice, 55:5 (2015), 323-8, doi: 10.1016/j.scijus.2015.03.004.

38 M. A. Guimarães, J. A. Soares-Vieira, R. H. Alves da Silva and M. P. Evison, 'A Standard Procedure for Accommodating Forensic Anthropological and Genetic Analysis of Decomposing Human Remains from Tropical Climates', Forensic Science International: Genetics Supplement Series, 2:1 (2009), 165-6, doi:10.1016/j. fsigss.2009.08.087.

39 J. A. D. Melki, C. C. S. Martin and A. L. Simões, 'Exhumation Procedures for Investigating the Genetic Links in Bones', Revista Saude Publica, 35:4 (2001), 368-74.

40 J. A. D. Melki, C. C. S. Martin and T. Zerbini, 'Scanning Electron Microscopy as an Auxiliary Method in the Study of Exhumed Bones', Forensic Science International, 206:1-3 (2011), e67-70, doi: 10.1016/j.forsciint.2010.09.004. 
41 Brasil, Portaria No 567/MD, de 29 de Abril de 2009. Criação do Grupo de Trabalho Para localização, Recolhimento e Identificação de Mortos da Guerrilha do Araguaia (Brasil, República Federativa do, 2009), http://pfdc.pgr.mpf.mp.br/atuacaoe-conteudos-de-apoio/legislacao/direito-a-memoria-e-a-verdade/portarias/ portaria\%20567.pdf (accessed 9 October 2015).

42 Globo, 'CEMEL de Ribeirão deixa programa para investigar ossadas no cemitério de Perus', O Globo, 22 May 2014, http://g1.globo.com/sp/ribeirao-preto-franca/ jornal-da-eptv-2edicao/videos/t/edicoes/v/cemel-de-ribeirao-deixa-programapara-investigar-ossadas-no-cemiterio-de-perus/3364332/ (accessed 27 October 2015).

43 Guimarães, 'The Challenge of Identifying Deceased Individuals in Brazil'.

44 M. A. Guimarães, R. A. Francisco, R. Abreu e Souza and M. P. Evison, 'Forensic Archaeology and Anthropology in Brazil', in W. J. M. Groen, N. Márquez-Grant and R. C. Janaway (eds), Forensic Archaeology - A Global Perspective (New York, Wiley Blackwell, 2015), pp. 215-22, 215.

45 P. E. Arns, Brasil: Nunca Mais - Um Relato Para a História (Petrópolis, RJ, Edicão Vozes, 1996).

46 Brasil, Portaria Interministerial no 1. Reformula o Grupo de Trabalho Criado pela Portaria no 567-MD, de 29 de Abril de 2009' (República Federativa do Brasil, 2011), http://www.normasbrasil.com.br/norma/portariainterministerial-1-2011_228607.html (accessed 9 October 2015).

47 M. A. Guimarães, R. A. Francisco, S. B. Garcia, M. P. Evison, M. E. de C. Pinheiro, I. X. Amaral, D. Santana and J. A. G. Patrício, 'Forensic Investigation, Truth and Trust in the Context of Transitional Justice in Brazil' (2017, forthcoming). 